\title{
Identifikasi Senyawa Metabolit Sekunder pada Durian (Durio zibethinus Murr)
}

\section{Identification of Secondary Metabolite Compounds in Durian Leaves (Durio zibethinus Murr)}

\author{
Aji Suteja1), E Harso Kardhinata'2), dan Rosliana Lubis ${ }^{3)}$ \\ 1\&3)Program Studi Biologi, Fakultas Biologi, Universitas Medan Area, Indonesia \\ 2)Program Studi Agroteknologi, Fakultas Pertanian, Universitas Sumatera Utara, Indonesia
}

\begin{abstract}
Abstrak
Penelitian ini bertujuan untuk mengetahui cara mengidentifikasi jenis senyawa metabolit sekunder yang terkandung pada daun durian. Penelitian dilakukan dengan metode eksperimental dengan cara mengidentifikasi senyawa metabolit sekunder pada daun durian dengan menggunakan skrining fitokimia. Kriteria sampel yang digunakan adalah bagian pucuk daun dan seluruh helai daun (kecuali tulang daun). Hasil dari penelitian menunjukkan bahwa dari tiga jenis daun durian yaitu jenis tembaga, bakul dan Sp A. terdapat beberapa jenis senyawa metabolit sekunder yang antara lain alkaloid, steroid, dan terpenoid. Analisa skrining fitokimia dilakukan dengan menggunakan kromatografi lapis tipis dengan menunjukan nilai RF pada tiga jenis daun durian dengan menggunakan pelarut metanol dan etil asetat dengan perbandingan 3:1. Nilai RF pada durian tembaga sebesar 0,97, pada durian bakul 0,95 dan durian Sp. A 0,94.
\end{abstract}

Kata Kunci: Metabolit Sekunder, Daun Durian, Nilai Rf, Skrining Fitokimia

\begin{abstract}
This study aims to determine how to identify the types of secondary metabolite compounds contained in durian leaves. The study was conducted by an experimental method by identifying secondary metabolite compounds on durian leaves using phytochemical screening. The sample criteria used were the leaf buds and all the leaf strands (except the leaf bones). The results of the study showed that of the three types of durian leaves namely copper, baskets and Sp A. There are several types of secondary metabolite compounds including alkaloids, steroids, and terpenoids. Phytochemical screening analysis was carried out using thin layer chromatography by showing RF values on three types of durian leaves using methanol and ethyl acetate solvents in a ratio of 3: 1. RF value on copper durian is 0.97, bakul durian is 0.95 and Sp durian. A 0.94.
\end{abstract}

Keywords: Secondary Metabolite, Durian Leaf, Rf Point, Phytochemical Screening

*E-mail: ajisuteja93@gmail.com

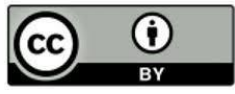


Suteja, A., Kardhinata, E.H., dan Lubis, R, Identifikasi Senyawa Metabolit Sekunder Pada Daun Durian (Durio zibethinus Murr)

\section{PENDAHULUAN}

Durian (Durio zibethinus) merupakan salah satu tanaman asli Asia Tenggara yang beriklim tropis basah seperti Indonesia, Thailand dan Malaysia (Ashari, 1995). Durian yang terdapat di Indoneaia memiliki berbagai varietas, terdapat 21 kultivar durian unggul yang dirilis oleh Dinas Pertanian, yaitu : Petruk, Sukun, Sitokong, Kani, Otong, Simas, Sunan, Sihijau, Sijampang, Siriwig, Bokor, Perwira, Sidodol, Bantal mas, hepe, Matahari, Aspar, Sawah mas, Raja Mabah, Kalapet, dan Lai Mansau (Untung, 2008).

Durian (Durio zibethinus Murr,) yang dijuluki The King of Fruit merupakan salah satu buah cukup popular di Indonesia. Buah yang memiliki rasa dan aroma yang khas ini sangat digemari oleh berbagai banyak orang. Rasa buahnya yang manis dan aroma harum buahnya menjadi daya tarik tersendiri bagi pecinta durian. Warna daging buahnya bervariasi, ada yang berwarna putih, kuning, dan oranye serta buah ini dilengkapi dengan adanya kandungan kalori, vitamin, lemak, dan protein. Akan tetapi kurang dalam hal pemanfaatannya. Selama ini, bagian buah durian yang lebih umum dikonsumsi adalah bagian salut buah atau dagingnya. Jika dilihat kegunaan durian ternyata bukan hanya daging buahnya yang dikonsumsi, tetapi jika digali lebih dalam lagi dapat ditemukan berbagai manfaat dari semua bagian buah durian tersebut, misalnya batang dari durian dapat digunakan sebagai bahan bangunan (Purnomosidhi et al, 2007). Selain itu, bagian daun durian juga diketahui memiliki kandungan senyawa aktif beupa metabolit sekunder yang bermanfaat bagi kesehatan.

Penelitian ini bertujuan untuk mengidentifikasi jenis senyawa metabolit sekunder yang terkandung dalam daun durian. Metabolit sekunder merupakan senyawa organik yang berasal dari sumber alami tumbuhan, yang dapat memberikan efek fisiologis terhadap makhluk hidup. Pada umumnya merupakan senyawa bioaktif. Senyawa metabolit sekunder dapat berupa alkaloid, flavonoid, terpenoid, steroid dan tanin (Rizal, 2011).

Analisis senyawa metabolit sekunder dari tanaman dapat menggunakna metode skrining fitokimia. Dengan menggunakan kromatografi lapis tipis. Kromatografi Lapis Tipis Yaitu kromatografi yang menggunakan lempeng gelas atau alumunium yang dilapisi dengan lapisan tipis alumina, silika gel, atau bahan serbuk lainnya. Kromatografi lapis tipis pada umumnya dijadikan metode pilihan pertama pada pemisahan dengan kromatografi. Kromatografi lapis tipis dengan penyerap penukar ion dapat digunakan 
untuk pemisahan senyawa polar. Harga RF yang diperoleh pada kromatografi lapis tipis tidak tetap, jika dibandingkan dengan yang diperoleh pada kromatografi kertas. Oleh karena itu pada lempeng yang sama di samping kromatogram zat yang di uji perlu dibuat kromatogram zat pembanding kimia, lebih baik dengan kadar yang berbeda-beda (Dirjen POM, 1979).

\section{METODE PENELITIAN}

Penelitian dilaksanakan di Laboratorium Kimia Universitas Medan Area, Sumatera Utara. Metode yang digunakan dalam penelitian ini adalah metode eksperimental. Dengan cara mengidentifikasi senyawa metabolit sekunder, yang terdiri dari alkaloid, flavonoid, terpenoid, steroid, tanin dan saponin. Sampel yang digunakan adalah daun durian, dengan kriteria sampel yang digunakan bagian pucuk daun dan seluruh helai daun (kecuali tulang daun).

\section{Sampel Penelitian}

Sampel penelitian berupa daun durian diperoleh dari terdiri dari 3 jenis durian yaitu jenis bakul, jenis tembaga dan jenis Sp A. Daun durian dikeringkan hingga memiliki kadar air 10\%, sampel tersebut digerus hingga halus menjadi serbuk.

\section{Ekstraksi Sampel}

Ekstrasi sampel dilakukan dengan metode maserasi, pelarut yang digunakan adalah metanol dan n-heksan. Serbuk sampel dimaserasi dengan pelarut tersebut selama 1x24 jam ekstrak yang diperoleh dipekatkan dengan rotary evaporator. Ekstrak pekat yang diperoleh siap dianalisa secara kualitatif (skrining fitokimia) untuk penentuan senyawa metabolit sekunder.

\section{Identifikasi Alkaloid}

Identifikasi alkaloid dilakukan dengan metode mayer, wagner dan dragendroff. 1gram ekstrak pekat daun durian ditambah dengan $1 \mathrm{ml} \mathrm{HCl} 2 \mathrm{~mol}$ dan $10 \mathrm{ml}$ aquadest dipanaskan selama 2 menit, didinginkan dan kemudian disaring. Filtrat dibagi menjadi 3 bagian, Masing- masing ditambah dengan pereaksi mayer, pereaksi wagner dan pereaksi dragendroff.

\section{Identifikasi Flavonoid}

Identifikasi flavonoid dilakukan dengan melarutkan ekstrak pekat daun durian dalam metanol panas dan ditambahkan 0,1g serbuk mg dan 5 tetes $\mathrm{HCl}$ pekat. 
Suteja, A., Kardhinata, E.H., dan Lubis, R, Identifikasi Senyawa Metabolit Sekunder Pada Daun Durian (Durio zibethinus Murr)

\section{Identifikasi Terpenoid dan Steroid}

Identifikasi terpenoid dan steroid dilakukan dengan melarutkan ekstrak pekat daun durian dalam 0,5 ml kloroform, kemudian menambahkan 0,5 ml anhidrida asetat dan menetesi campuran dengan $2 \mathrm{ml} \mathrm{H}_{2} \mathrm{SO}_{4}$ pekat melalui dinding tabung identifikasi tanin

\section{Identifikasi Tannin}

Identifikasi tannin dilakukan dengan melarutkan ekstrak pekat daun durian dalam $10 \mathrm{ml}$ aquadest kemudian disaring dan filtrat ditambah dengan 3 tetes $\mathrm{FeCl}_{3} 1 \%$.

\section{Identifikasi Saponin}

Identifikasi saponin dilakukan dengan melarutkan ekstrak pekat daun durian dalam $10 \mathrm{ml}$ air panas kemudiandikocok kuat-kuat selama 15 detik.

\section{HASIL DAN PEMBAHASAN}

Hasil uji skrining fitokimia metabolit sekunder daun durian dari 3 jens sampel tersaji pada tabel 1. berikut ini.

Tabel 1. Hasil Skrining Fitokimia Daun Durian

\begin{tabular}{|c|c|c|c|}
\hline \multirow{2}{*}{ Uji } & \multicolumn{3}{|c|}{ Sampel } \\
\hline & Durian tembaga & Durian bakul & SpA \\
\hline Alkaloid & ++ & +++ & +++ \\
\hline Flavonoid & - & - & - \\
\hline Saponin & - & - & - \\
\hline Steroid & +++ & ++ & +++ \\
\hline Terpenoid & +++ & ++ & +++ \\
\hline Tannin & - & - & - \\
\hline \multicolumn{4}{|c|}{ Keterangan: $(-)=$ tidak adanya senyawa $(++)=$ adanya senyawa $(+++)=$ adanya senyawa kuat } \\
\hline \multirow{3}{*}{\multicolumn{4}{|c|}{$\begin{array}{l}\text { Berdasarkan hasil skrining fitokimia yang dilakukan terhadap sampel daun } \\
\text { durian (tabel } 1 \text { 1) menyatakan bahwa ekstrak methanol dan n-heksan dari sampel } \\
\text { daun durian memberikan informasi, bahw ekstraksi tersebut memiliki senyawa } \\
\text { metabolit sekunder terdiri dari alkaloid, terpenoid dan steroid. }\end{array}$}} \\
\hline & & & \\
\hline & & & \\
\hline \multicolumn{4}{|c|}{ Tabel 2 Perhitungan Nilai RF untuk Ketiga Jenis Sampel Durian } \\
\hline & Sampel & Pelarut (3:1) & Nilai RF \\
\hline & Durian tembaga & Methanol etil asetat & 0,95 \\
\hline & Durian bakul & Methanol etil asetat & 0,97 \\
\hline & $\mathrm{SpA}$ & Methanol etil asetat & 0,94 \\
\hline
\end{tabular}

Berdasarkan tabel 2 di atas diketahui nilaik RF terbesar yaitu pada sampel durian bakul dengan nilai 0,97. Sedangkan untuk durian tembaga dan durian SpA masing - 
masing nilai RF nya adalah 0,95 dan 0,94 . Nilai RF yang terbentuk tidak berbeda jauh diantara ketiga sampel.

Terbentuknya endapan pada uji Mayer, Wagner dan Dragendorff berarti dalam ekstrak methanol daun durian terdapat alkaloid. Tujuan penambahan $\mathrm{HCl}$ adalah karena alkaloid bersifat polar, diekstrak dengan pelarut methanol. Hasil positif alkaloid pada uji Mayer ditandai dengan terbentuknya endapan putih. Diperkirakan endapan tersebut adalah kompleks kalium-alkaloid. Pada pembuatan pereaksi Mayer, larutan merkuri klorida ditambah kalium iodide. Jika kalium iodida yang ditambahkan berlebihan maka terbentuk kalium tetraioddomerkurat menurut Svehla (1990).

Alkaloid mengandung atom nitrogen yang mempunyai pasangan atom nitrogen yang mempunyai pasangan elektron bebas sehingga dapat digunakan untuk membentuk ikatan kovalen koordinat dengan ion logam menurut Merliana dkk (2005). Pada uji alkaloid dengan pereaksi Mayer, diperkirakan nitrogen pada alkaloid akan bereaksi dengan ion logam $\mathrm{K}+$ dari kalium tetraiodomerkurat membentuk komplek kalium-alkoloid yang mengendap. Pada pembuatan pereaksi Wagner, iodin bereaksi dengan ion I dari kalium iodide menghasilkan ion I yang berwarna coklat. Pada uji Wagner, ion logam K akan membentuk ikatan kovalen koordinat dengan nitrogen pada alkaloid yang mengendap.

Hasil positif alkaloid pada uji Dragendorff ditandai dengan terbentuknya endapan coklat muda sampai kuning. Endapan tersebut adalah kalium- alkaloid. Pada pembuatan pereaksi Dragendorff, bismuth nitrat dilarutkan dalam $\mathrm{HCl}$ agar tidak terjadi reaski hidrolisis karena karena garam-garam bismut mudah terhidrolisis membentuk ion bismutil (BiO). Agar ion $\mathrm{Bi}^{3}$ tetap barada dalam larutan itu ditambah asam sehingga kesetimbagan akan bergeser kearah kiri. Selanjutnya ion $\mathrm{Bi}^{3}$ dari bismuth nitrat bereaksi dengan kalium iodide membentuk endapan hitam Bismut iodide yang kemudian melarut dalam kalium iodide berlebih membentuk kalium tetraiodobismulatmenurut Svehla (1990). Pada uji alkaloid dengan pereaksi Dragendorff, nitrogen digunakan untuk membentuk ikatan kovalen koordinat dengan $\mathrm{K}_{+}$yang merupakan ion logam. Pada uji Dragendorff, Wagner dan Mayer masing-masing dilakukan 2 kali pengulangan. Hasil yang diperoleh adalah semua positif alkaloid, maka dapat disimpulkan bahwa dalam ekstrak methanol daun durian mengandung alkaloid.

Identifikasi terpenoid dan steroid pada ekstrak methanol n-Heksan daun durian memberikan hasil positif baik pada terpenoid atau steroid yaitu terbentuknya cincin coklat pada batas larutan saat ditambah dengan $\mathrm{H}_{2} \mathrm{SO}_{4}$ serta terlihat warna hijau 
Suteja, A., Kardhinata, E.H., dan Lubis, R, Identifikasi Senyawa Metabolit Sekunder Pada Daun Durian (Durio zibethinus Murr)

saat larutan diteteskan pada plat tetes. Perubahan warna seperti disebutkan diatas dikarenakan terjadinya oksidasi pada golongan senyawa terpenoid/steroid melalui pembentukan ikatan rangkap terkonjugasi. Kondensasi atau pepepasan $\mathrm{H}_{2} \mathrm{O}$ dan penggabungan karbokation. Reaksi ini diawali dengan proses asetilasi gugus hidroksil menggunakan asam asetat anhidrida. Gugus asetil yang merupakan gugus pergi yang baik akan lepas, sehingga terbentuk ikatan rangkap. Selanjutnya terjadi pelepasan gugus hydrogen beserta elektronnya, Senyawa ini mengalami resonansi yang bertindak sebagai elektrofil atau karbokation.

\section{SIMPULAN}

Dari penelitian yang dilakukan dapat disimpulkan bahwa ekstrak methanol dan etil asetat daun durian mengandung senyawa metabolit sekunder yang terdiri dari alkaloid, terpenoid dan steroid.

\section{DAFTAR PUSTAKA}

Ashari S. (1995). Hortikultura Aspek Budaya. Jakarta : Universitas Indonesia Press. Dirjen POM. (1979). Farmakope Indonesia Edisi III, Departemen Kesehatan RI Jakarta Marliana dkk. 2005. Skrining Fitokimia Dan Analisis Kromatografi Lapis Tipis Komponen Kimia Buah Labu Siam (Sechium edule Jacq. Swartz) dalam Ekstrak Etanol. Biofarmasi. 3(1):26-31

Purnomosidhi. (2007). Perbanyakan dan budidaya tanaman buah: durian, mangga, jeruk, melinjo, dan sawo. Pedoman lapangan edisi kedua. World agroforestry Centre (ICRAF) dan Winrock Internasional. Bogor. Indonesia.

Rizal. (2011). Pengolahan Data Penelitian Menggunakan SPSS 17.00. Jakarta. Cipta Pustaka.

Svehla. (1990). Vogel Buku Teks Analisis Anorganik Kualitatif Makro Dan Semimikro. Jakarta: PT. Kalman Media Pustaka.

Untung. (2008). Durian Untuk Kebun Komersial dan Hobi. Penebar swadaya Jakarta. 